\title{
Local Policy Support Direction for Non-State-Owned Museums under the Museum Regulations
}

\author{
Bo-Lin $\mathrm{SU}^{1, *}$ \\ ${ }^{1}$ BoLin Su, graduate student of Journalism and Communication major in \\ University of Electronic Science and Technology of China, Chengdu, Sichuan, China \\ 751731895@qq.com \\ *Bo-LIN SU
}

Key words: non-state museum, policy research, text analysis

\begin{abstract}
: this paper first performs a comprehensive narration of the policy researches on non-state-owned museum, and confirmed that in the researches on non-state-owned museums at present, the research on supporting policy is insufficient. Then, according to the research on the supporting direction of the museum regulations, the paper summarizes six key problems that exist in the policy support for the non-state-owned museums. On this basis, the paper performs text analysis on the local policies for non-state museum in some areas of our country, and found the problems of talent guarantee and cooperation between museums are most important in the six problems. Finally, based on the previous findings, the author put forward some advice for improvement, and looks forward to making some contributions to the development of non-state museum.
\end{abstract}

\section{Introduction}

Since entering the new century, the non-state-owned museum gradually taking scale, the research directions are mainly concentrated in the identity orientation of non-state-owned museum, current situation, difficulties, sustainability, thinking of policy system and other aspects connected to the development of non-state museum, also includes the problems of relevant policy system and macro management level design for non-state-owned museum. The paper "The current situation, problems and policy thinking of private museum development” written by professor Liu Jiansong and Liu Minjie of Fudan University pointed out that the problems of private museum include its own irregular unprofessional operation, and the difficulties of establishment, operation and development faced by the museums". It suggests that the "development policy" should include "standard and improved access system, endow equal legal status with public museums, and standardize the sources and management of collections, strengthen business guidance, make and implement supporting policies in the development plan” and other major initiatives.[1]"Chinese contemporary private museum macro management research" written by professor Song Xiangguang of Peking University in his monograph "Objects and knowledge: the theory and practice of contemporary China Museum" pointed out that in recent years, the theoretical problems related to the private museum is weakening, but the academic consensus is waiting the " the promulgation of related policy and the management measures ", " from the qualitative research to practical question". The private museum is a " hybrid of the private and the public", the competent authorities should recognize the role of it, " take development in the first place", manage department should in " the form of macro management, indirect management and collaborative management", and perform "classification guidance ", " adhere to the public, independent, encourage innovative and sustainable principle". [2]

At present, the research of the macro management of the non-state-owned museums in our country emphasize on the problems of the non-state-owned museums and call for supporting policies, or focus on the aspect of the unprofessional and nonstandard of the non-state-owned museums. But in fact, it should be taken into account that regulate and manage, foster and encourage policy is an organic whole. The research on the local supporting policies of the non-state-owned museums is the basis for the improvement of relevant policies, such research is the 
weak link in the research of the non-state-owned museums. Therefore, this paper focuses on the study of the latter, perform text analysis on the existing part of the policy, and then focus on policy support, summarize the omission of the support aspects, so as to put forward some suggestions for improvement.

\section{The History of the Policy Development of the Non-State-Owned Museum in China}

From the promulgation of "provisional regulations on the registration and administration of private non enterprise units" in 1998 to the promulgation of "People's Republic of China cultural relics protection law " in 2002, our country has gradually established a dozens of a non-state-owned-museum, which located in Beijing, Shanghai, Guangdong, Chongqing, Zhejiang, Liaoning, The biggest difference of this phase is the beginning of the non-state-owned museum registration policy, the non-state-owned museum has its own legal identity. [3]

In 2010, the State Bureau of Cultural Relics in "The advice to promote the development of non-state-owned museums" pointed out non -state-owned museum non-profit social service agency which aims at education, research, and appreciation, established by social force, use non state-owned cultural relics, samples, materials and assets, qualified as a legal person and open to society. " [4] so far, China has made a clear definition of the non-state-owned museum. State Administration of cultural heritage, annual inspection records show that at the end of 2014, the number of museums in China has reached 4510, 982 non-state-owned museums, increase oy345 compared to 2013. [5] It shows that: the non-state-owned museum has a certain scale and began to form a certain social influence.

February 9, 2015, the "Museum regulations" official release by the State Council 659th, implement from March 20th, this is the first national administrative law documents in national museum field. The regulation definite the museum as a non-profit organizations aims at education, research, and appreciation, collect, protect and display the witness of the human activities and the natural environment to the public, and registered in the registration administration.[6] The difference between the state-owned museums and non-state-owned museums mainly reflected in the source of the assets of establishment, use or mainly use state-owned assets to establish a museum is state-owned museums; use or mainly use non state-owned assets to establish a museum is non-state-owned museums.

The "Regulations" clearly put forward the fair treatment of state-owned museums and non-state-owned museums. In the museum set up, finance and taxation support, professional title assessment, endeavor the non-state-owned museums and state-owned museums equivalent treatment, clear the status and nature of non-state-owned museums in legal aspect. [7] On the whole, the implementation of the museum regulations has a very important significance for China's non-state-owned museums further development.

After the promulgation of "Museum regulations", local government formulated the corresponding policy according to regulations, in order to implement the "Regulations". Such as the general office of the people's government of Shandong Province issued " The advice to promote the development of non-state-owned museums", Nanjing People's government issued "Nanjing non-state-owned museums development implementation measures", Guangdong Provincial Department of finance, the Provincial Department of Culture jointly formulated "Guangdong Province encourage private museum construction special funds management approach" and so on. The promulgation of these local policies is the embodiment of the specific implementation of the regulations, but also the direct support for the development of non-state-owned museums. The author will carry on the text analysis on them, so as to explore the key point and the neglected part of the local policy support. 


\section{Text Analysis and Policy Interpretation of Local Support Policies of Non-State-Owned-Museums}

\section{Definition of Text Analysis}

Before the definite text analysis, we should first understand the concept of text. The word "text" come from the "texere" in Latin, the meaning is "fluctuation, linkage, interleaving, weaving", and thus derived the meaning of "construction, building, establishment or manufacturing ". Some western scholars believe that the text is not only the words, but also the production. On the one hand, it is the physical movement of textile; on the other hand, it is also a modification and concept. [8]. The definition of "text" in the west is defined from the two aspects of symbol and material bearing. The text is not only the language operation, but also fixed on the object language symbol. Some scholars believe that the text means the language operation, the transmission symbol, which is fixed on the object or through a variety of media. In this way, the text can be more than the words, but also include oral, body language, as well as the film, television and other forms of [9].

Text analysis refers to a series of relevant texts to be compared, analyzed and integrated according to the need of a certain research topic, and extracts the comments from it. Text analysis belongs to qualitative analysis, through the text of the word sentences and the interpretation of the symbols, the results are always make a comment for the fact information. The text analysis method is a resolving process based on the actual situation of the text, the steps are not fixed, generally for text access, identification evaluation, classification and finishing [10]. Text analysis in this paper refers to a series of steps including classification, arrangement, content analysis, and features narration of the policy text.

\section{Text Analysis on Part Local Policies}

For selection of local policy analysis samples, this paper chooses "The advice to promote the development of non-state-owned museums" issued by Shandong Province and "Nanjing implementation measures to promote the non-state-owned museums development". There are two reasons for selection: 1: the two measures are both based on museum regulation, which the local government agencies state clearly. Therefore, it can be sure they are the local policy samples which based on the interpretation of museum regulation.. 2: Local policies in line with the text research content, the sample can be used for the study is too small, and the exclude of no reference to the "Museum regulations", the optional sample is only the two samples mentioned above.

Non-state-owned museums have many problems in the operation and maintenance after the establishment. To sum up, it can be classified into two main aspects: the rigidity requirement that can be quantified and the problems more inclined to environmental factors. The analysis on the sample will start from these issues, based on the interpretation of the text to draw the focus and missing part of local supporting policies.

Rigid conditions under which most is can intuitively reflect in the concrete operation process of a non-state-owned Museum, rather than environmental factors, the impact of a non-state-owned Museum more directly, where a lack of will lead to non-state owned museums run crisis, serious and even lead to non-state-owned-museum closed.

Rigidity requirement1: Sources of funds

In the problems faced by the non-state-owned museums, financial is the core problem. The founders of non-state-owned museum of the museum normally need to raise fund by themselves, and self-financing, which make the problem is relatively prominent. At present, most of the non-state-owned museums cannot achieve the balance of payments, even resulting in permanent close.

Rigidity requirement2: land and house

Land and house is one of the essential elements of the museums, because there is no supporting policy of cultural land transfer or preferential lease or purchase for non-state-owned museums, therefore, non-state-owned museums may cost large number of fund for the land and house and influence the sustainable development of museum, or forced to locate in an address with a lower price, and traffic inconvenience, in deserted suburban areas, which reduces the museum's social 
influence.

Rigidity requirement3: Collection source

The collection is the foundation of a museum. Non-state-owned museums have many problems in the source, rating and collection in and out. The exhibition of the museum needs to be updated regularly, and the realization of the educational function of the museum is based on the quantity and quality of the collection. In the field of private collection, due to financial problems, it is difficult to achieve this.

Compared with the rigidity requirement, the direct influence of environmental factors on non-state-owned museums is weak. However, environmental factors are related to the long-term development of non-state-owned museums, if neglect the environmental factors after solving the problem brought by the rigidity requirement in daily operation, it will greatly restrict the sustainable development of the non-state-owned museums.

Environmental factor1: legal status

At present, the legal status of the non-state-owned museum is still the "private non enterprise legal person" . "Private non enterprise legal person" generally refers to the private schools, hospitals and so on., the legal status in the actual operational level resulted in application difficulties for non-state-owned museums in registration, land, finance, taxation and other policy aspects.

Environmental factor 2: display design

The display design of the non - state - owned museum is the embodiment of the comprehensive quality of the non - state - owned museum. The core function of the museum is education, mainly through the scientific, lively and interesting exhibition way to achieve. In terms of a non-state-owned museums, exhibition is difficult to achieve such a high level, and even the basic explanation of the collections also have defects.

Environmental factor3: Professionals

At present, most of the non-state-owned museums have serious problems of professional talents. On one hand, the non-state-owned museums are eager to enroll the professionals, especially the talents of the major of collection and museums. On the other hand, for low salary, and obstacles in professional title evaluation and other considerations, few graduates or employee with the background of collection and museums would like to work in the non-state-owned museums. This situation forms a vicious circle that is difficult to solve.

After the analysis of the two samples, it can be found that, although there something are worthy of recognition in the regulations, it not only clear the provisions of funds that support non-state-owned museums, but also mentioned the encouragement for the introducing of museum professionals. However, there are still some problems in the sample rules, which are summarized as follows:

At first, there is no specific measures to help the non-state-owned museums, which is like the state-owned museums. In fact, there are related cases, for example, Turpan Museum, Zhengzhou Huaxia Culture and Art Museum, the Museum of Zhejiang Province and Haining Xie art collections have supporting and helping relationship, this win-win relationship is acceptable for both sides. [11] If there are corresponding supporting policies this aspect, such successful cases can be promoted to a mature development path for the cooperation between state-owned museum and non-stated-owned museum. And in the study of the sample, only the "measures" published in Nanjing mentioned this point, and there is no specific promoting means.

Secondly, local policy is lack of the attention on the problem of non-state-owned museum staffs. This mainly reflects in the truth that talent treatments of the non-state-owned museum are lack of clear policy protection. Lack of the policy guarantee, the talent treatment of state-owned museums and non-state-owned museums has big difference, which results in the phenomenon that the non-state-owned museums is difficult to attract professional talents, and the ability improvement in exhibition, operations, and research also has been limited.

\section{Conclusion}

Although the promulgation of the "Museum regulations" bring a encouragement for the 
development of non-state-owned museums, it also established a more strict, and specific management norms. When the local government performs a stricter control on non- state-owned museums, it is also required to pay attention to the policy guidance, and the support of sustainable development. On the basis of existing supporting policies, the supporting direction of the direct fund supporting will transfer to indirect support of personnel transport, and museums cooperation. For the two aspects that the local policy has not cover, this paper puts forward the corresponding recommendations:

First, the government needs to bring the non-state-owned museum employees into same system of state-owned museum employees, and provide equal platform, solve the obstacle of the training, title, research, communication and guide more talents to work in non-state-owned-museum, and promote the flow of talent between the state-owned-museum and the non-state-owned museum. Only endeavor the guarantee of system and platform for the introducing of talents, can attract more professionals to participate in the construction of non-state-owned museum.

Second, the local governments should encourage state-owned-museum to help the non-state-owned museum, the state-owned-museum provide the assistance on the exhibition design, the cooperation of research, personnel training exchanges, and achieve cooperation and win-win in all aspects from multiple channels. Specific implementation can take reference of domestic successful examples, combine with the local actual situation, and start to promote from the connection of two museums.

Non-state-owned museum is a an important part in museum system in our country, formulate appropriate local ordinances and regulations based on the National Museum regulations to provide support is important for the whole development of the museum of our country. In the process, the focus gradually change from short-term funding support to the long-term sustainability policy support, in order to make the government to formulate the relevant local policy really revitalize its unsatisfying development trend at present.

\section{Acknowledgment}

This article was financially supported by "model research of museology resources of conversion utilization” for National Social Science Fund Project in 2014 (Project Number: 14BGL162).

\section{Reference}

[1]Liu Jiansong, Liu Minjie, The current situation, problems and policy thinking of private museum development, J. World of Antiquity, 2011.3.

[2]Song Xiangguang, Objects and knowledge: an analysis of the theory and practice of contemporary Chinese museums, Beijing, Science Press, 2009.

[3]State Administration of Cultural Relics Bureau and the Department of social heritage, In the new situation museum work practice and thinking, Beijing, cultural relics from publishing house, 2010.

[4]State Administration of cultural heritage, Ministry of civil affairs, Ministry of finance, Ministry of land and resources, Ministry of housing and urban rural development, the Ministry of culture and the State Administration of taxation.The advice to promote the development of non-state museum, 2010

[5]Assessment group of private museum standardization construction, Fu Yanhua, Wang Chao, Assessment report of private museum standardization construction, Chinese museum, 2014.2

[6] The state council of the People's Republic of China, The museum regulation, 2015.1

[7]The state council of the People's Republic of China, The museum regulation, 2015.1

[8]D.C.Greetham, Theories of the Text, OxfordUniv Press, 1999.

[9]Jorge.J.E.Gracia, Text:ontologicalstatus, identity, author, audience, State University of New York 
Press, 1996.

[10]The research on the comparison of content analysis and text analysis [EB/OL], http://Summersound.Space.live.com.

[11]Wang Jing, State-owned private museum and non-state-owned museum: a long way to go - take the support of Zhejiang Haining Xie art collection as an example, J. Journal of museum research, 2015.1. 